\title{
Sartre, Intersubjectivity, and German Idealism
}

\author{
Sebastian Gardner
}

This paper has two, interrelated aims. The first is to clarify Sartre's theory of intersubjectivity. Sartre's discussion of the Other has a puzzling way of going in and out of focus, seeming at one moment to provide a remarkably original solution to the problem of other minds and at the next to wholly miss the point of the skeptical challenge. The nature of his argument is equally uncertain: at some points it looks like an attempt to mount a transcendental argument, a kind of Refutation of Idealism regarding the existence of others, at others, to be a defence of direct realism; yet again, it can seem to propose a dissolution of the problem closely analogous to Wittgenstein. I will argue (Section I) that none of these provides quite the right model for understanding Sartre, which requires one to take seriously his method of resolving epistemological issues into matters of 'ontology'. I argue further (Section II) that Sartre's theory becomes fully coherent only if we make explicit its implicit presupposition of a conception of intersubjectivity articulated by Fichte.

My second aim is to pursue the connection opened up of Sartre with German idealism. To the extent that commentators attempt to relate Sartre systematically to German idealism, it is almost always Hegel who provides the other term of comparison. ${ }^{1}$ What I try to show (Section III) is that the usual comparison of Sartre with Hegel, which is largely negative, is distracting, and that Sartre's closer philosophical relations are to Fichte and Schelling. ${ }^{2}$ This supplies, I argue, an important correction to the tendency of anglophone discussion of Sartre to isolate his claims from historical considerations, or to restrict Sartre's historical frame of reference to Hegel, Husserl and Heidegger: Sartre's philosophy, I suggest, is viewed fruitfully in the context of philosophical debates pursued in early German idealism. Sartre's ethics, I argue (Section IV),

\footnotetext{
${ }^{1}$ See Catalano, Commentary on 'Being and Nothingness', Hartmann, Sartre's Dialectic, Schroeder, Sartre and his Predecessors, Theunissen, The Other, ch. 6, and 'Sartres negationstheoretische Ontologie der Zeit', Seel, Sartres Dialektik, and Williams, Hegel's Ethics of Recognition, pp. 371-80.

${ }^{2}$ Sartre's place in a tradition of transcendental reflection on the self going back to Fichte is recognised, but the only commentary known to me which takes the broader view for which I argue in this essay is Frank, Zeitbewußtsein, pp. 77-
} $85,92-3,100 f f$. 
provide supporting evidence for this view. I propose tentatively in conclusion (Section V) a corresponding view of existential phenomenology as a whole.

\section{Sartre's theory of intersubjectivity}

Philosophical theories of intersubjective cognition - in analytic parlance, solutions to the problem of other minds - may be classified along several dimensions. First, we may distinguish between theories that locate the ground of intersubjective cognition (i) by descent from the level of persons as a whole to the subpersonal level of their elements or component parts, (ii) by ascent to a supra-personal level, and (iii) exclusively at the level of whole persons. Second, we may distinguish between (i) naturalistic theories, and (ii) theories which maintain that intersubjective cognition has non-naturalistic, thus 'metaphysical', grounds.

Third, an associated distinction may be drawn between (i) theories which construe intersubjective cognition as fundamentally dependent on an empirical causal relation, and (ii) theories which deny that any such relation is fundamental to intersubjective cognition.

These distinctions are rough, and not exhaustive, but they help to establish the philosophical geography. The following alignments are familiar. At the one extreme are the theories of the German idealists, distinguished by their commitment to supra-personal and non-naturalistic grounds of intersubjective cognition. At the other extreme are naturalistic, sub-personal theories which maintain that our knowledge of others is achieved by way of empirical causal relations between behavioural acts and the causes thereof, and empirically formed (perhaps innate, hard-wired, neurally realised) representations of these. In the territory that lies between these extremes, which it is tempting to think of as that of 'common sense' or 'the natural attitude', various permutations are possible. Sartre's theory, like Wittgenstein's, appears to belong here. Sartre insists on locating the ground of intersubjective cognition at the level of whole persons: Sartre takes it as a guiding principle throughout his discussion that knowledge of others cannot be grounded on bodily facts and causal relations involving them (what he calls 'realism'), nor that we are permitted to make reference in our account of intersubjective cognition to any standpoint transcending that of the individual subject (this being what he deplores in Hegel, BN 239-40, and criticises as also present, in 
modified form, in Heidegger, BN 245-6). ${ }^{3}$ Furthermore, though Sartre's philosophical project as a whole is of course anti-naturalistic, there is room for thinking that his theory of intersubjectivity, or the core of it that is worth reconstructing, involves no breach with the mild naturalism of common sense, nor any denial that empirical causal relations are essential to intersubjective knowledge. What I will be attempting to show is that, these initial appearances to the contrary, Sartre's theory stands very much closer to the German idealist end of the spectrum. That this should be so is, furthermore, no accident, for on my view, though I shall not be able to defend this claim here, Sartre's philosophical project as a whole should be understood as exemplifying the pattern of strategy laid down by Kant, and repeated many times in post-Kantian philosophy: a systematic transcendental metaphysics - capable of rebutting or at least holding its own against philosophical naturalism, and either idealistic in character or developed through a transformation of Kantian idealism - is constructed with a view to realising certain axiological ends. ${ }^{4}$ In Sartre's case, the underlying and motivating axiological conception consists in an understanding of value in terms of freedom, conceived non-empirically, like Kant, but detached from its Kantian moral interpretation.

In the celebrated passages that follow his detailed critique of earlier theories of intersubjective cognition, Sartre describes two different scenarios in which I achieve intersubjective awareness. In the first I identify a figure standing over there in the park as another subject, another for-itself, and Sartre's account of what follows concerns itself with the transformation that this generates in my relation to the in-itself (BN 254-6). (The world is 'decentralised', the lawn assumes a new orientation towards a point with which I am not identical, the world exhibits a 'fixed sliding' away from me and 'drains' out of my grasp.) In the second scenario I am discovered peeping through a keyhole - I hear the footsteps approaching from behind, and am overcome with shame (BN 259-61). Here Sartre concentrates on the impact on my self-relation, the difference made by the gaze of the other to how I apprehend myself. (I apprehend myself as possessed of a new kind of range of properties, the determination of which eludes my choice - my freedom has been 'stolen'.) Though the shame/keyhole scenario comes later in Sartre's text, it has epistemological priority: it is

\footnotetext{
${ }^{3}$ Page references to Being and Nothingness are prefixed 'BN'. Quotations are based on Barnes' translation but amended in light of the original.

${ }^{4}$ See my 'Value and idealism' and 'German idealism I'.
} 
because and only because I have the form of awareness of others exemplified in the shame/keyhole scenario that I can have the form of awareness of others exemplified in the park scenario. In the park, I am aware of the 'other-as-object'; in the keyhole case, I am aware of the 'other-as-subject'. It is only because awareness of the other-as-subject is possible, that awareness of the other-as-object is possible.

What is the solution to the problem of intersubjectivity which the shame/keyhole illustration allows us to grasp, according to Sartre? Ultimately it is simply this: that I am capable of 'a sort of cogito concerning' the Other (BN 251); 'the cogito a little expanded [...] reveals to me as a fact the existence of the Other' (BN 282); 'the cogito of the Other's existence is merged with my own cogito' (BN 251); 'certain particular consciousnesses [...] bear indubitable witness to the cogito both of themselves and of the existence of the Other' (BN 273); awareness of the Other thus 'shares in the apodicity of the cogito itself' (BN 250). ${ }^{5}$

How is Sartre's solution supposed to work? The key claims which constitute Sartre's account, and distinguish it from other attempted solutions, are, I take it, the following.

1. Knowledge of the other is achieved primordially through phenomena such as shame, that is, phenomena where the for-itself undergoes an ontological transformation (BN 261). This is not a metaphor and, I will be arguing, Sartre does not intend the transformation to be reducible to anything epistemological.

2. The specific kind of ontological transformation effected by the other is understood in terms of Sartre's basic opposition of two modes of being, self-identical, fully positive being-in-itself, and non-self-identical, negative, being-for-itself. It consists in the formation, out of the latter, of something that is supposed to share in the character of being-in-itself while retaining the character of consciousness (BN 262-3). The status of the newly created 'properties' or 'characteristics' of the human subject in its being-for-others - like that of the other items in Sartre's ontology that intermediate being and nothingness, including négatités, imaginary objects, values, and 'we'-being - may be described as Meinongian; they subsist in the gulf that separates being-in-itself and being-for-itself.

In order to grasp Sartre's conception of this transformation, we need to look to the conception that he has of 'corrupt' or 'degraded' consciousness, as it appears in other places in his writings, beginning with

\footnotetext{
${ }^{5}$ See also BN 268.
} 
and most clearly in The Transcendence of the Ego. ${ }^{6}$ In this early work Sartre is concerned not with relations to others but with the source of our conception of ourselves as having objective, empirical existence, existence as 'persons' in the Strawsonian sense. Sartre says that this arises as follows:

'We have been learning to distinguish "the psychic" from consciousness. The psychic is the transcendent object of reflective consciousness. It is also the object of the science called "psychology" [...] The ego is on the side of the psychic [...]

[...] The ego is a virtual locus of unity, and consciousness constitutes it in a direction contrary to that actually taken by the production: really, consciousnesses are first; through these are constituted states; and then, through the latter, the ego is constituted. But, as the order is reversed by a consciousness which imprisons itself in the world in order to flee from itself, consciousnesses are given as emanating from states, and states as produced by the ego. It follows that consciousness projects its own spontaneity into the ego-object in order to confer on the ego the creative power which is absolutely necessary to it. But this spontaneity, represented and hypostatized in an object, becomes a degraded and bastard spontaneity, which magically preserves its creative power even while becoming passive. Whence the profound irrationality of the notion of an ego.

We are familiar with other degraded aspects of conscious spontaneity $[\ldots]$ We are thus surrounded by magical objects which retain, as it were, a memory of the spontaneity of consciousness, yet continue to be objects of the world [...] This is also why we are sorcerers for ourselves each time we view our me.' (pp. 71, 81-2)

\footnotetext{
${ }^{6}$ Important places in Being and Nothingness include xxx on consciousness misconceived as a quality, 158-70 on psychic temporality (esp. 162-3 on 'the Psyche'), 335ff and 347 on pain and the body, 354 on the constitution of the psychic, 442 on 'states of consciousness' as the 'idol of a positive psychology', and 473 on 'false psychic objects as motives'. See also War Diaries, pp. 230-1, on desire, and the 'illusion of immanence' discussed in The Psychology of Imagination and said to be 'the point of view of common sense' (p. 3).
} 
In Being and Nothingness, the role that is accorded here to self-apprehension is reallocated in part to the gaze of the other, but the conception of 'degraded', pseudo-reality remains constant, as does Sartre's intention of inverting common sense's understanding of the world (a point to which I return below under 7).

It should be stressed that the 'properties' which the other 'bestows' on me through its gaze are not to be conceived as pre-existing, even in a latent form, the advent of intersubjectivity (BN 222). They no more pre-exist intersubjectivity by existing in me implicitly than consciousness exists implicitly in its objects. The 'discovery' (BN 221) of the new ontological domain which is opened up by intersubjectivity is consequently not a discovery of facts but of a new set of possibilities, somewhat in the sense that one may speak of discovering a new game to be played.

3. It is a crucial and distinguishing feature of Sartre's account that intersubjectivity consists primordially in an extra-mundane, subject-subject relation: 'it is not in the world that the Other is first to be sought' (BN 273); when the Other 'looks at me, he is separated from me by no distance, by no object of the world [...] by no body in the world, but by the sole fact of his nature as Other' (BN 270). ${ }^{7}$ This follows from his description of other-awareness as cogito-like, and his contrast of the park case, where I look 'across the world' to the other, with the shame/keyhole case, where the other appears 'on my inside', is designed to bring out the point.

\footnotetext{
${ }^{7}$ See Theunissen, The Other, pp. 200-2. The notion of a 'subject-subject relation' is of course liable to misunderstanding and needs to be handled with care. The following quotations show Sartre struggling with the difficulty of finding a characterisation of the subject-subject relation that does not imply a relation of the same kind that the subject has with objects: 'If the Other is to capable of being given to us, it is by means of a direct apprehension' (BN 250); 'The Other is present to me without any intermediary as a transcendence which is not mine' (BN 270); 'At the same time I experience the Other's infinite freedom' (BN 270); 'I experience the inapprehensible subjectivity of the Other directly and with my being' (BN 270); 'consciousnesses experience one another without intermediary' (BN 301); 'He is given not as a being in my universe but as a pure subject' (BN 270); 'However that other consciousness and that other freedom are never given to me; for if they were, they would be known and would therefore be an object' (BN 271). We thus find Sartre saying that the other is 'apprehended' and 'experienced' by me, 'present to me', and both 'given' and 'never given' to me. This explains why ultimately Sartre should rest it all on the analogy with the cogito: his claim is simply that I have to the other the same kind of relation - whatever it is; however one may term it - as I have to myself.
} 
For Sartre, the objectual world is not interposed between subjects in any way that would accord it epistemic significance, either positive or negative. The supposition that the objectual world functions in intersubjective cognition as an epistemological vehicle reflects a misconception of the for-itself as, in Sartre's terms, an item that is intra-mundane in the same sense as an inkpot, since only if the other were a part of the objectual world would it be necessary for the world to play an epistemic role in opening up others to me. The only sense in which the objectual world enters primordially into intersubjective relations is just that it is what provides the determinate content of the consciousnesses of mine which the other subjects to ontological transformation (BN 270).

4. The relation that obtains primordially between individual for-itselves is an ontological relation, a relation of being, as opposed to a relation of knowledge (BN 233, 239, 243, 244, 247, 251, 271). This is said repeatedly in the chapter on others, and it follows from Sartre's general view (again, repeated many times over, e.g. BN 619: 'the ontological problem of knowledge is resolved by the affirmation of the ontological primacy of the in-itself over the for-itself') that knowledge in general supervenes on consciousness and that consciousness is being and not knowing. The identification of consciousness with knowing is a mistake of which Sartre accuses Hegel (BN 238-40). It follows that, because consciousness is being, intersubjective consciousness is primordially a relation of being, and only derivatively and correlatively a relation of knowledge.

5. The relation that obtains between individual for-itselves is a negative ontological relation. ${ }^{8}$ In intersubjectivity this takes the form of a relation of mutual ontological antagonism and exclusion: the being of the one for-itself tends to diminish the being of the other, and vice versa; to the extent that the one has or

\footnotetext{
${ }^{8}$ See BN 230, 238, 252, 283, 298-301. Sartre talks of being 'affected by' the upsurge of the Other (BN 231), existencefor-others as a 'radical refusal' of the Other (BN 252), the appearance of the Other as 'undermining' my centralisation of the world (BN 255), the Other as entailing 'a negation effected by me upon myself' (BN 283), 'negating' my transcendence (BN 326), 'the secret death of my possibilities' (BN 323), a 'refused self' (BN 284), 'the Not-Me-notobject', 'the collapse of Myself' (BN 285), and so on.
} 
gains being, the other lacks or loses being; each has being at the other's expense. The relation may be conceived on the analogy with two opposed physical forces.

6. The negative ontological relation just described comes into existence not by virtue of the mere joint existence of two for-itselves, but rather their existence under certain conditions, namely their mutual orientation or mutual intentional directedness. Crucially, this condition for ontological transformation is conceived by Sartre as non-epistemic. It does later take an epistemic form, but it is not primarily and in the first instance an epistemic condition: the fulfilment of cognitive conditions is a necessary correlate of the ontological relation, since the transparency of consciousness ensures that whenever the for-itself is ontologically transformed, it knows itself to undergo its transformation.

In sum, it would be highly misleading to say that for Sartre, at the level of philosophical explanation, I feel shame (in the keyhole/shame scenario) because of what I know (think, believe etc.) of what the other thinks of me, i.e. to interpret 'the effect that another has on me' as an effect that is achieved through my knowing of the other. We are of course easily misled into thinking that the significance of the other's gaze is epistemic, that Sartre is here conceiving vision as an epistemic power, and so that I feel shame because I know/believe that the other knows/believes me to be peeping. However, the real meaning of the gaze is instead that of an action; again, we do better to think of it on the analogy with the application of a physical force. Sartre thus reverses the ordinary order of explanation: on his account, it is not because we gain knowledge of others that we are ('psychologically') affected by them; it is because we are ontologically (and not merely 'psychologically') affected by others that we have knowledge of them. That I $d o$ have knowledge of the other is therefore not denied by Sartre, but is counted in to the total configuration knowledge is the correlate of the other's ontological effect on me, not the cause of that effect.

The 'reef of solipsism', the problem of the seeming unknowability of the Other, is consequently, in Sartre's view, non-existent (BN 250-1): the impression we have of an intraversible epistemic gulf between self and other, issuing in skepticism about other minds, results from mistaking what is in fact the negative ontological relation between for-itselves, for a negative (or absent) epistemological relation; and this a consequence of the more general mistake of identifying consciousness with knowledge, and of supposing that the relation of self to other is mundane. It is thus to be noted, and stressed, that the source of the whole 
'problem of other minds', on Sartre's account, has nothing whatever to do with privacy, the imperceptibility or non-spatiality of the mental, or any epistemic differential between physical objects and thoughts or sensations - all of these standard reasons for holding that the other is epistemically inaccessible play no role for Sartre; they figure in his account only as correlates of the negative ontological relation.

It should also be noted that what one might call the 'Stroud' question, the one that famously interferes with transcendental argumentation - Does Sartre's account show that there must really be an other, or merely that I must represent there being an other? - has no application to Sartre's account, as he formulates it. Within Sartre's framework, to raise that question, to entertain the doubt, is to deny the being of one's own consciousness: 'I experience the inapprehensible subjectivity of the Other directly and with my being' (BN 270). The same strategy is employed by Sartre in the Introduction to provide an 'Ontological Proof' of the external world (BN xxxvi-xxxviii). Certainly Sartre's general notion that such apodictic ontological intuition is possible is open to criticism, but it supplies a basic premise of his whole argument regarding intersubjectivity, and once granted it eliminates the distinction of belief from fact that renders classic transcendental arguments vulnerable to Stroud.

7. It follows from what was said above (under 3) that it is not the body that provides the key to knowledge of others. The body, like the objectual world at large, plays no epistemic role in Sartre's account, neither negatively inhibiting, nor positively enabling knowledge of others (BN 223-4, 230-1). It does not screen one mind from another, nor is it what allows one mind to disclose itself to another ('the body is not that which first manifests the Other to me', BN 339). In this lies one of Sartre's major differences from Merleau-Ponty, for whom embodiment does provide the key to (the first grade of) intersubjective cognition, and from Strawsonian views of the topic.

It is true that on Sartre's account the for-itself is necessarily embodied, just as it is necessarily intersubjective in its being. But these two necessities are independent: it is not because we are embodied that we are able to know one another. Intersubjective cognition and embodiment are two independently necessary moments in the structure of the for-itself. To the extent that there is any interdependence between these two moments, it goes the other way: if there were no intersubjective knowledge, then embodiment would be impossible since, as Sartre makes clear in the chapter on the body, the body as 'object', as 
something that the other can see at the door alongside the keyhole, presupposes the existence and gaze of others (BN 351-2). ${ }^{9}$ The body in its only other existential mode, as subject, is not equipped to play a privileged epistemic role, since the body as subject is as thoroughly subjective as consciousness itself. ${ }^{10}$ And between these two ontological modes of the body there is for Sartre nothing intermediate (this being, again, a key point of Merleau-Ponty's challenge). In addition, it is to be noted that the necessities of embodiment and intersubjectivity are not of the same order, and have different sources: the necessity of intersubjectivity is (as discussed below) 'factual' or 'contingent', and not one of the for-itself's ontological structures (BN 282), while embodiment is an ontological structure, derived directly from the for-itself's structures of facticity and temporality (BN 306ff). ${ }^{11}$

If it is asked how, unless I am first situated bodily in front of the keyhole, and how, unless my body exists originally as a perceptible physical object, the other can see me and thereby put me to shame, then the answer is that these questions, in so far as they are intended to contradict Sartre's analysis, imply a conception of the order of things that Sartre, for better or worse, rejects. To the extent that the order of causal dependence between empirical states of affairs expressed in these claims is part of common sense, Sartre's metaphysics is undoubtedly and consciously revisionary. In terms of the distinctions of kinds of theory of intersubjectivity that I drew earlier, Sartre denies not just that empirical causal relations, involving my body and other 'empirical objects', are fundamental to intersubjective cognition, but that they play any role at all in it, either at the transcendental level or at the level of determinate cognition of others. Sartre's non-causal analysis here mirrors exactly his analysis of human action into a configuration of hermeneutically and teleologically interconnected elements from which empirical, efficient causality is excluded (BN 433-50). As the earlier passage from The Transcendence of the Ego shows, Sartre intends to reverse commonsensical orders of explanation, and in Being and Nothingness this is extended from our understanding of human personality to the world at large. The fact that in consequence Sartre's system appears from an external or commonsense point of view to leave explanatory gaps (e.g. 'how do we know

\footnotetext{
${ }^{9}$ Transcendence of the Ego, pp. 90-1: body is 'illusory fulfilment of the I-concept'.

10 'Consciousness (of) the body is a lateral and retrospective consciousness of what consciousness is' (BN 330) and 'only that'; it lacks 'anatomical and spatial constitution' (BN 339).

${ }^{11}$ On the relation of temporality and embodiment in Sartre, see Frank, Zeitbewußsein, pp. 84-5, 108-9.
} 
the identity of a given body-as-object with the corresponding body-as-subject?') is not an argument against it: it simply refers us to the question of the ultimate justification of Sartre's project as a whole, a topic which cannot be discussed here.

8. The 'objectification' theme in Sartre's account of intersubjectivity - his thesis that intersubjectivity is interdependent with self-alienation, on the basis of which he rejects (Hegel's) intersubjective 'optimism' (BN 240,285 ) and asserts that the form of intersubjective relations is necessarily conflictual - is therefore inseparable from his account of intersubjective cognition. ${ }^{12}$

The only way in which the two could be separated - in which one could retain Sartre's solution to the problem of intersubjective cognition, while declining his intersubjective pessimism - is by making fundamental alterations to his ontology: one would need to either strip the in-itself of its negative, alienating character, or affirm that in intersubjectivity a qualitatively new order of being which is not merely that of 'degraded' consciousness is created by the synthesis of being-in-itself and being-for-itself. Both involve denying that the opposition of in-itself and for-itself is absolute. Merleau-Ponty thus appears quite right to

\footnotetext{
${ }^{12}$ It is thus not due, on my account, to Sartre's confusion of a weak 'logical' sense of ('intentional') object with a loaded, alienating sense of object. In this connection, see Honneth, 'Erkennen und Anerkennen: zu Sartres Theorie der Intersubjectivität'. Aquila, in 'Sartre's other and the field of consciousness', gives a highly original reading of Sartre's theory in terms of modified Husserlian notions of noesis, noema and field of consciousness, which does imply that Sartre's theory of intersubjectivity should be detached from his account of concrete relations (see pp. 255-6). Without disputing the implication, and whether or not it succeeds in overcoming the reef of solipsism, Aquila's theory seems to me an extension of Husserl in the light of Sartre, and not to capture all of Sartre's account. Aquila resolves the puzzle that Sartre, on the one hand, appears to operate in the light of the Husserlian distinctions of fact/essence and noesis/noema, treating intersubjectivity as some sort of essence for phenomenological description, and on the other hand, regards Husserl's methodology as allowing no exit from solipsism. Aquila's analysis of the Look in terms of the other's encompassing (transcending) my transcendence (of my own facticity) omits, however, the idea of ontological transformation described above under 2; it implies that the advent of the Other leaves the ontological status of my facticity untouched, i.e. that the Other makes only an epistemological difference to my self-relation.
} 
regard this move against Sartre as decisive, and necessary for his non-conflictual picture of intersubjectivity. ${ }^{13}$

Sartre maintains, then, that the solution to the problem of intersubjective cognition consists in there being a 'sort of cogito concerning' the Other, the occasion of which is the for-itself's ontological transformation. As said earlier, this is a thin solution. But it is not vanishingly thin, and its thinness does not count against its being a solution. ${ }^{14}$ It needs to be asked, however, whether it provides adequate explanation in terms of Sartre's own conception of the form that philosophical explanation should take. Pursuing this question will lead to my contention regarding the relation of Sartre's theory of intersubjectivity to German idealism.

One question that Sartre's theory may be expected to answer, and that receives an answer in other theories of intersubjectivity, concerns the multiplicity of for-itselves. Why are there others, and why are there many others? Sartre has a response to this question that at least goes part of the way and is internally consistent. Sartre terms the existence of others a 'factual' or 'contingent necessity' (BN 250, 282), not an obviously helpful phrase, but one the sense of which can be gleaned by looking at other places in his text, for he uses it in several contexts. ${ }^{15}$ Phenomenological ontology leads to the identification of certain highly abstract, universal ontological structures - in the first instance, the being of the in-itself and that of the foritself or consciousness. These ontological structures are, and give themselves as, groundless, beyond explanation, original, underivable. They thus have aspects of both contingency and necessity: they are necessary in so far as, having no foundation beyond themselves, they appear to provide their own foundation, and they are contingent in so far as they either lack any internal self-necessitation (being-initself is not God) or appear arbitrary in relation to prior structures of being (being-for-itself depends on but is gratuitous in relation to - it is not necessitated by - being-in-itself). To say that the existence of others is a 'contingent necessity' is thus to say that the existence of others in general is a (very high-level) 'brute fact'. As for the existence of a multitude of particular others, this is answered in the same way. The fact that

\footnotetext{
${ }^{13}$ See Phenomenology of Perception, pt. III, ch. 3.

${ }^{14}$ As Aquila puts it, 'it is simply a matter of attending to a dimension of one's world ...' ('Sartre's other and the field of consciousness', p. 271).

${ }^{15}$ See the remarks on modality at BN xxxi, xlii, 84 .
} 
others are many amounts to nothing more than the contingent necessity, for each individual other, that it exists. ${ }^{16}$

The contrast of the other in general with particularised others raises an epistemological issue. Even supposing that it overcomes solipsism, Sartre's account leaves unanswered, as he himself notes (BN 277-80), a residual, 'empirical' question: How do I know, in any given concrete and particular instance, that I really am confronted by an other and not deceived or in error? How is the transition to be made from cognition of the 'Other in general', the possibility of which Sartre may be allowed to have shown, to cognition of this particular other, about which he has so far (compare Wittgenstein or Merleau-Ponty) said next to nothing? ${ }^{17}$

It is often claimed that this signifies an ultimate and fatal weakness in Sartre's account. ${ }^{18}$ In my view, however, this is mistaken, for if we have followed Sartre in tracing back the ground of intersubjectivity as far as a 'cogito concerning' the other, then the question has been quashed. The question asks for - for this alone could provide it with an answer - 'criteria', empirical conditions for the justified application of the concept 'other person'. Now, Sartre's view of the problem of intersubjectivity and his view of its solution are interdependent, and in the course of showing how cognition of the other is in general and in principle possible, Sartre has also shown what sort of entity we are concerned with, and that this is not something that could be controlled by criteria: anything that could be nailed down by empirical criteria for

\footnotetext{
${ }^{16}$ At one point Sartre may seem to give a different answer, in so far as he describes at BN 283-5 a reciprocal relation of 'refusal of the Other' and 'reinforcement' or 'choice of selfness', that might be taken to suggest that for-itselves are mutually individuating ('co-responsible'). Since however Sartre's position can hardly be that for-itselves generate each other's being, the 'selfness' in question must be interpreted - as indeed the phrase 'reinforce' suggests - as pertaining not to the fundamental identity of the for-itself but to a later stage in the dialectic of self and other.

${ }^{17}$ The objection that Sartre does not account for particularity should be distinguished from another, similar criticism made by Merleau-Ponty (see Phenomenology of Perception, pt. II, ch. 4): namely that even if we grant that Sartre's intersubjective cogito may establish a relation of being to other for-itselves, it is inexplicable for Sartre how I actually perceive others in their bodies. Sartre's reply, however, is to reject the explanandum: if it seems to us that we have such 'perceptions', then the seeming is an illusion (on a par with that of one's own personal substantiality).

${ }^{18}$ Theunissen points out (The Other, pp. 240-3), rightly, that Sartre faces the same kind of difficulty that he alleges in Heidegger (BN 247-9), of making the transition from the ontological to the ontic. The correct conclusion, I suggest, is that Sartre's criticism of Heidegger should be overturned: Sartre is mistaken in thinking that there is a difficulty here.
} 
concept application could not be the other, the other subject, knowledge of which we are trying to account for. The skeptical question about our criteria is therefore logically unanswerable - a ground for transcendental solipsism, were it not for the (unique) alternative offered us by Sartre. Our situation of lacking empirical criteria is, furthermore, not one that we can rationally regret: our 'lack of criteria' is one with our freedom, and if our situation strikes us as epistemologically precarious, then this is only because, refusing the absoluteness of our subjectivity, our freedom, we cling to the idea that intersubjectivity must rest on a mundane causal chain stringing one worldly mind to another. After phenomenological ontology has done its cleansing work, we accept our freedom, surrender to facticity, and cease to ask whether bodies of such and such a shape and size are ones that 'inform us' of other minds. ${ }^{19}$

A theological analogy may be drawn. A theist troubled by doubts about the basis of faith in revelation ought to be reassured by a proof that God must reveal Himself somewhere sometime, and that when He does so, He will be recognised. The theist cannot ask theology for more: he cannot ask for times and places, without compromising God's transcendence. The analogy of course seems inappropriate, because we regard knowledge of God as 'extra'-ordinary, in contrast with the 'ordinary' status of knowledge of others. It is, however, part of the force of Sartre's account that this - empiricist's, commonsense - contrast is false: 'ordinary' cognition has exactly the structure of 'extraordinary' cognition. (It is not an accident that this view of the structural parity of knowledge of others with knowledge of God is Jacobi's, and that Fichte, in a passage quoted below, the parallels of which with Sartre will be noted, attempts to show the consonance of his own views with those of Jacobi. ${ }^{20}$ )

\footnotetext{
${ }^{19}$ Sartre's perspective on the problem of other minds is characteristic of transcendental philosophy and follows the pattern of Kant's solution to the epistemology of the external world, where the first move is to distinguish empirical or transcendental externality, each case then receiving a different epistemological treatment. The genuine philosophical task relates to the Other conceived extra-empirically, for with regard to the Other conceived as an empirical item, there is no project of philosophical explanation to be pursued and no skeptical case to be answered.

${ }^{20}$ See Jacobi, Main Philosophical Writings, p. 231, and the solipsism charge in 'Jacobi to Fichte', pp. 497-27. Honneth, in 'Erkennen und Anerkennen: zu Sartres Theorie der Intersubjectivität', pp. 74-5, notes that, prior to Sartre, Fichte alone in the tradition of intersubjectivist philosophy regards it as imperative that our knowledge of others is beyond doubt.
} 
This reading of Sartre explains why the distinction often drawn between solutions and 'dissolutions' of the problem of other minds should be hard to apply to Sartre's theory of intersubjectivity: Sartre's theory, in common with that of many others, including Wittgenstein, involves a reconception of what is at issue which makes it impossible to say whether, at the end of the day, the skeptical demand for justification has been met or repudiated. It explains also why Sartre does not anywhere in his long chapter give an epistemological statement of the problem of the Other, and refers to epistemological difficulties only when identifying the problems confronted by realism, idealism, etc. The problem that Sartre does recognise as existing genuinely and prior to philosophical theorising is instead the problem, stated in the first paragraph of the chapter and in ontological form, of accounting for 'a being which is my being without being-for-me' (BN 221). This, he says, is what requires us to consider the question 'of the existence of the Other' (BN 222). If my reading of Sartre is correct, then, to the extent that this question 'of the existence of the Other' may be given epistemological form, it is answered by (i) Sartre's theory of the cogito concerning the other, which (in conjunction with the original datum of my consciousness of 'a being which is $m y$ being without being-forme') suffices for a rejection of solipsism, (ii) his account of all further 'empirical' questions concerning knowledge the other as misconceived in the way described above; in all other respects, the question passes into the (practical) problem of how to relate my freedom to that of the other.

In order to determine more fully the adequacy of Sartre's theory of intersubjectivity, it would be necessary to scrutinise Sartre's general conception of philosophical explanation, in particular, his practice, first set out in the Ontological Proof, of providing ontological solutions to epistemological problems. Strictly this goes beyond the scope of this paper, which only requires it to be pointed out that in general Sartre regards the ontology/knowledge distinction as fundamental and ontology as the answer to epistemology. Something may nevertheless be said briefly about this strategy. What is an ontological relation, as opposed to a relation of knowledge, for Sartre? Clearly the load that Sartre assigns to the notion is heavy, and at some point it will be wondered if Sartre has not merely switched labels. However, Sartre's understanding of the distinction and its value is not mysterious. Sartre supposes, uncontentiously, that epistemic states such as belief are distinguished by their justificatory dimension, and that questions of justification are formulated in contrast with questions of being (to ask if I am justified in believing $\mathrm{p}$ is not, as such, to ask about the being of anything). For Sartre, epistemological problems are answered - or circumvented - by phenomenological 
disclosure of relevant structures of being. Phenomenological insight is not directly articulated as a justification, a reason for belief, but once achieved, reflection on it reveals the search for justification to be at an end, or the need for justification not to exist.

Clearly, Sartre's method is continuous with Heidegger's strategy for disposing of skepticalepistemological problems, even though Sartre rejects Heidegger's distinction of Vorhandensein and Zuhandensein. The further questions that need to be considered include therefore (i) whether the ontological strategy misses the point of, and simply amounts to a dogmatic repudiation of, epistemology, (ii) whether Sartre's version of Heidegger's strategy, by restoring the centrality of consciousness, cancels one of its conditions of legitimacy. ${ }^{21}$ It is hard to see that the answer to the first is a straightforward 'yes'. Nor does the latter appear obviously correct, since Sartre's restoration of consciousness is accompanied by a reconception of consciousness as ontological, which appears to make appeal to Heidegger's thesis of the priority of Vorhandensein unnecessary.

The final point to be made is this. Sartre says nothing about what makes cogito-like intersubjectivity possible. ${ }^{22}$ If we compare Sartre's account of intersubjectivity with his account of subjectivity, it becomes clear that there is an asymmetry. If we ask how the relation of myself to myself is possible - How is selfconsciousness possible? - then to this question Sartre has an ample, whether or not ultimately adequate, answer: he tells us that the structure and unity of the for-itself consists in its being a separation across the multiple and interrelated dimensions of reflection, temporality, and facticity/transcendence. The symmetrical question regarding the self-other relation, however, is not provided by Sartre with any answer. And yet the designation of intersubjective consciousness as 'cogito-like' invites the obvious question: If the twin dimensions of immediacy and reflexivity are related essentially within the cogito - i.e. if it is more than an accident that what the cogito gives me immediate consciousness of is something that happens to be $I$ myself - then how can the former dimension be decoupled from the latter? How can immediacy survive without reflexivity? To be sure, there is no strict inconsistency in holding that other subjects are given, as

\footnotetext{
${ }^{21}$ A full consideration of this issue would need to return not just to Heidegger but also to the vexed question of Husserl's relations to skepticism.

${ }^{22}$ The closest he comes is in the 'metaphysical' discussion of intersubjectivity that closes the chapter on others (BN 297302), though its bearing remains oblique, for reasons given below in note 32 .
} 
other, in the same immediate mode as one is 'given' to oneself (to repeat, being minimal does not preclude being a solution). But it is natural to wonder if more could not be said. ${ }^{23}$

\section{Fichte, Sartre and trans-individual intersubjective metaphysical structure}

I want now to compare Sartre's position with that of Fichte.

Fichte, famously threatened with solipsism by his theory of the absolute Ich, advances a transcendental proof of the existence and epistemic accessibility of others, starting from the premise that I have knowledge of my freedom (as effective in the empirical world), and arguing by way of the concept of the 'summons' or 'demand' (Aufforderung) for recognition addressed to me by the other, to the necessity of my presupposing the existence outside me of other finite intelligences with whom I am in communication. ${ }^{24}$ Fichte holds to the existence of a trans-individual intersubjective metaphysical structure. Fichte's affirmation of such a structure is clear in these statements from his The Vocation of Man: ${ }^{25}$

'I am aware of appearances in space to which I transfer the concept of myself: I think of them as beings like myself. Speculative philosophy, taken to its conclusion, has taught me or will teach me that these supposed rational beings outside of me are nothing but products of my own mind [...] But the voice of my conscience calls to me: whatever these beings may be in and for themselves, you ought to treat them as self-subsistent, free, autonomous beings completely independent of you [...]

\footnotetext{
${ }^{23}$ While accepting the tension just indicated in Sartre's account, I disagree therefore with both Theunissen and Hartmann, who suggest that the mix of subjectivist methodology and objective ontology in Sartre's theory is actually incoherent: see, respectively, The Other, pp. 206-7, and Sartre's Ontology, p. 206.

${ }^{24}$ See Foundations of Natural Right, $\S \S 1-4$.

${ }^{25}$ This work comes later in his development than the transcendental argument from Foundations of Natural Right just described: here Fichte elaborates on the significance of his earlier conclusions, without rehearsing the argument itself. I ignore here all questions of a change in Fichte's views. Schelling's System of Transcendental Idealism (pt IV) restates Fichte's theory, making clear its commitment to intersubjective metaphysical structure through use of the concept of preestablished harmony and emphasising the idea of reciprocal action as the basis of intersubjective cognition.
} 
strictly speaking it is not thought by which they are first presented to me as such. It is the voice of conscience, the commandment, "here limit your freedom, here suppose and respect other purposes".' (The Vocation of Man, p. 76)

'My lawful will [...] is to have consequences [...] every dutiful determination of my will is to have an effect in another world which is incomprehensible to me [...] What am I thinking when I think this? [...] I assume such a law of a spiritual world [...] to which my will and the will of all finite beings are themselves subject $[\ldots]$ The law of the supersensible world would therefore be a will [...] Between it and all finite rational beings there is a spiritual bond [...] I flow into that will; and it is the voice of conscience within me [...] This will unites me with myself; it unites me with all finite beings like me and is the general mediator between all of us [...] it is a world or a system of a number of individual wills: that union and direct interaction of a number of autonomous wills with each other; a secret which already in the present life lies clearly open to everyone's view without anyone noticing it or bothering to wonder about it [...] how I can know of them [other autonomous beings] is simply incomprehensible $[\ldots]$ How do they enter my world $[\ldots]$ ? How are free spirits informed about free spirits [? ...] In short, this mutual knowledge and interaction of free beings already in this world is quite incomprehensible according to laws of nature and of thought [...]'. (Ibid, pp. 104-9)

Fichte's differences from Sartre are obvious. To the extent that Fichte's ultimate ground is moral as well as practical, Fichte proceeds from a basis that is not Sartre's. ${ }^{26}$ Because Fichte thinks that conscience has transcendental necessity - his argument being that it is necessary that we hear the voice of conscience Fichte thinks it possible to give a discursive proof of the other, which Sartre does not. ${ }^{27}$ There is also, and consequently, a difference regarding necessity and contingency: the existence of others is straightforwardly, 'absolutely' necessary for Fichte, but a 'contingent necessity' for Sartre.

\footnotetext{
${ }^{26}$ Though not alien to Sartre's position in Existentialism and Humanism.

${ }^{27}$ Although, interestingly, Fichte - and the general transcendental style of proof that he employs - is omitted from Sartre's critical review of attempts to overcome the reef of solipsism.
} 
There are also similarities. Fichte and Sartre agree that solipsism lies in wait for any reflection that seeks to make intersubjectivity dependent on empirical causal relations: intersubjectivity is, Fichte says, 'incomprehensible according to laws of nature'. And Fichte's idea that the reality of the other is manifested immediately and non-discursively in the felt experience of conscience parallels Sartre's privileging of affective consciousness; in both cases the heart of this non-discursive experience (though interpreted differently) consists in a confrontation with the freedom of the other. Fichte's account of the other as acting on me coincides with, as I interpreted it, Sartre's account of the gaze. ${ }^{28}$

Holding aside these differences and similarities, and concentrating simply on what results from Fichte's argument, the point I now wish to make is simply this: Fichte's conception of Metaphysical Intersubjective Structure provides what is missing from Sartre's account of intersubjectivity, namely an explanatory ground of intersubjective cogito-like connectedness. ${ }^{29}$

If this move is available to Sartre, why does he not make it? The explanation is not oversight. Sartre gives his reasons clearly and repeatedly: he considers that any admission of a supra-personal Intersubjective Metaphysical Structure would (i) undermine the radical individuality of the for-itself, (ii) contradict the perspectival character of intersubjectivity, ${ }^{30}$ and (iii) falsify its fundamentally disharmonious, unsynthesised character (BN 231-2, 252, 246-7, 252, 297-302, 413ff.).

Now to the extent that Intersubjective Metaphysical Structure is identified with Hegel's Geist, Sartre's repudiation of it makes good sense, since Hegel's Geist carries with it a conception of the radical sociality of individuals and a promise of ultimate intersubjective rationality, both denied by Sartre. ${ }^{31}$ However, it is not true - as the case of Fichte shows - that Intersubjective Metaphysical Structure necessarily takes the form of a Hegelian ' $I$ that is a $W e$ '. It is one thing to conceive this Structure, thinly, as an enabling ground of intersubjectivity, and another to attribute to it an imminent rationality; the latter,

\footnotetext{
${ }^{28}$ See Williams, Hegel's Ethics of Recognition, p. 377.

${ }^{29}$ The intelligible, 'spiritual' as opposed to sensible, twist that Fichte gives the structure may be regarded, from Sartre's point of view, as a matter of idiom.

${ }^{30}$ See Theunissen, The Other, pp. 206-7.

${ }^{31}$ To this extent Sartre's rejection of Hegel is on target, even though, as is often noted, he misunderstands Hegel in many other ways; see e.g. Williams, Hegel's Ethics of Recognition, pp. 379-80.
} 
richer conception depends on other things, which Hegel argues for but to which Sartre is not committed. The Structure can be conceived merely as the ground of inter-relation of multiple subjects, implying only a weak conception of the collective unity of subjects. Intersubjective Metaphysical Structure is therefore available to Sartre on his own terms, not just as part of the Hegelian package, which it puts him under no pressure to accept: it can simply provide the indeterminate ground, the 'whatever it is', that facilitates cogito-like intersubjectivity. Specifically, the bare concept of Intersubjective Metaphysical Structure does not imply (a) that there is a point of view of the Structure on individual for-itselves, a supra-individual perspective on individuality, nor (b) that the concept of the Structure is phenomenologically manifest in intersubjective experience, nor (c) that the Structure is an ontological ground of the plurality of individuals in the sense of a creative source of for-itselves, nor (d) that the Structure subsists independently of individual subjects in general (only of particular individual subjects). ${ }^{32}$

What is true - and I will come back to this - is that, having granted Intersubjective Metaphysical Structure, possibilities may then present themselves for determining it further, and further determination may lead to the ascription to it of some of the attributes (a)-(d). Sartre may not welcome this prospect, but the fact that it is opened up by the admission of Intersubjective Metaphysical Structure cannot be a reason for not making the initial admission, if this has, as I have suggested, a justification within Sartre's own terms.

So far I have argued only that Sartre's account allows itself to be supplemented in German idealist manner. But now I want to give a reason for thinking that this is supplement is necessary. The reason derives from the observation that a logical problem appears in his theory of other minds if we do not follow it through in

\footnotetext{
${ }^{32}$ The passages which best display Sartre's reasoning, at BN 299-300, show clearly that the only notion of Intersubjective Metaphysical Structure considered by Sartre is the Hegelian one, marked by attributes (a)-(d), of 'a being "I-and-the-Other'" which is such that 'my selfness and that of the Other are structures of one and the same totality of being', a 'synthetic totality in terms of which one might claim to understand the plurality of consciousnesses' or 'foundation of the multiplicity of consciousnesses'. Part of the explanation for Sartre's restriction of the options to either Hegel or rejection of supra-personal structure lies in his alignment of these notions with, respectively, 'metaphysics' and 'ontology', a distinction which I criticise in the following section.
} 
the Fichtean way that I have suggested. If this problem does not come readily to our attention when we consider Sartre's theory of intersubjectivity, then this is, I suggest, because we implicitly read into his theory a Fichtean background.

According to Sartre, I know the Other because the Other objectualises me, and this objectualisation, I claimed, needs to be understood in terms of the action of the Other's consciousness on my own, and not reduced to a representation of mine, a taking-myself-to-be-gazed-at. The sense of 'because' here cannot, however, be one that implies any kind of real priority. For, if it were taken that way, then it would have to be asked: What makes possible the Other's awareness of me as a subject, which is required in order for the Other to objectualise me, this objectification being necessary, in turn, for me to become aware of the Other?

Evidently, this question - of the origin of the Other's presupposed knowledge of me-as-subject cannot be answered in the same way that the original question concerning my knowledge of the Other was answered, without sparking off an infinite regress. However, any attempt by Sartre to reject the question - to identify the scope of philosophical enquiry in full with the answer to the question how $I$ come to be aware of others, and to close down questions that go beyond the proximate source of my awareness of others - would be tantamount to an admission that his philosophical methodology commits him to transcendental solipsism.

What Sartre must suppose, therefore, is that the priority which the gaze of the Other has in the phenomenological reconstruction of each for-itself's accession to intersubjectivity is just that - a phenomenological and not a real priority. Phenomenological priority must be conjoined with ontological non-priority: if it must appear to me that (so to speak) you knew of me before I knew of you - that your knowing-of-me made possible my-knowing-of-you - and if the same appearance must present itself to you symmetrically but in reverse, then the only thing for me, for us, to think (all of the other, 'realist', 'idealist' etc., non-Sartreian options having been ruled out at an earlier point) is that there can be no relation of precedence between my advent to intersubjectivity and that of the Other, and that the episodes of our each coming to be aware of one another are mutually implying and mutually presupposing moments of a single, trans-individual structure. That is, Sartre must affirm Intersubjective Metaphysical Structure in the Fichtean sense. $^{33}$

\footnotetext{
${ }^{33}$ It may be noted that Aquila (giving a different sort of account from mine: see note 12 above) reaches a partially parallel conclusion, though he does not present it as a revision to Sartre's theory: 'Sartre needs to recognise an
} 


\section{The convergence of Sartre's metaphysics with German idealism}

This Fichtean supplement to Sartre's theory of intersubjectivity would be arbitrary and isolated, if Sartre's metaphysics had no other, positive points of contact with German idealism. In this section I will argue that this is not so, and that the historical gap between them conceals a deep convergence of Sartre's thought with the metaphysics of German idealism.

1. I begin with the conclusion of Being and Nothingness, the short penultimate section entitled 'In-itself and for-itself: metaphysical implications', in which Sartre returns to a question that he raised at the end of the Introduction concerning the unity of being-in-itself and being-for-itself (BN xliii and 3-4), i.e. the whole which, it may be speculated, they jointly compose.

In the first half of this section (BN 617-21) Sartre attempts to determine how much room for further explanation, if any, is left by the philosophical enquiry that he has just completed. He distinguishes several questions that may be asked about being and its two types (BN 619). The question of why there is being at all is answered by saying that (i) being itself is such that there can be no reason why it is,${ }^{34}$ and (ii) being as phenomenon is because of the for-itself which reveals it. ${ }^{35}$ There is however another question, which, Sartre asserts, is both legitimate and as yet unanswered: 'Why does the for-itself arise from being [à partir de l'être]?' Its answer is to be supplied by what Sartre calls 'metaphysics' as opposed to 'ontology', ontology being what his enquiry has hitherto comprised. ${ }^{36}$ The answer to the question would seem to be, Sartre asserts, that the in-itself gives rise to the for-itself in an attempt to found itself, to become its own cause. ${ }^{37}$

irreducible noetic structure' ('Sartre's other and the field of consciousness', p. 266). The conclusion of Zahavi, in Husserl and Transcendental Intersubjectivity, pp. 143-4, that Sartre falls back into 'apriorism', is also similar to the one that I have drawn, though again it is arrived at on different grounds.

34 '[T]he very definition of being releases to us its original contingency' (BN 619).

35 'The character of a phenomenon comes to being through the for-itself' (BN 619).

${ }^{36}$ The distinction of metaphysics from ontology is drawn earlier at BN 297.

${ }^{37}$ The idea is presented earlier at BN 81-2, 84. 
Sartre however hesitates, indicating what seems to be a contradiction in the idea that the in-itself can undertake a project, ${ }^{38}$ and affirms only that 'everything takes place as if - 'comme si' - it were so:

'ontology teaches us two things: (1) If the in-itself were to found itself, it could attempt to do so only by making itself consciousness [...] (2) Consciousness is in fact a project of founding itself [...] But we can not derive anything further from this. It is up to metaphysics to form the hypotheses which will allow us to conceive of this process as the absolute event which comes to crown the individual venture which is the existence of being. It is evident that these hypotheses will remain hypotheses since we can not expect either further validation or invalidation. What will make their validity is only the possibility which they offer us of unifying the givens of ontology.' (BN 620-1)

Now, two critical observations about Sartre's discussion. First, it is extremely unclear how the distinction of ontology and metaphysics is to be drawn. Sartre writes: 'We in fact apply the term "metaphysical" to the study of individual processes which have given birth to this world as a concrete and particular totality. In this sense metaphysics is to ontology as history is to sociology' (BN 619). However, since, as Sartre himself says, 'historical becoming' is not at issue in metaphysics (BN 621), this comparison fails to elucidate. Sartre also suggests an association of metaphysics with 'why' questions, but again unhelpfully: the ontology/metaphysics distinction cannot be one of description ('what is?') from explanation ('why is?'), since the ontology of Being and Nothingness is rich with explanation at all levels; 'phenomenological ontology' is no mere catalogue of existents. Nor are ontology and metaphysics related in the way that, in German idealism, analytical reflection and speculation, or divisive understanding and unifying reason, are related, since Sartre gives no suggestion that a new 'logic' or conceptual form is available for metaphysics which is not already available for ontology. The best that can be said, I conclude,

\footnotetext{
38 ' [I]t is through the for-itself that the possibility of a foundation comes to the world. In order to be a project of founding itself, the in-itself would have to be originally a presence to itself, that is to say, it would have to be already consciousness' (BN 621).
} 
is that ontology and metaphysics compose two stages of enquiry, two levels of explanatory extrapolation from the data; they do not form two species of enquiry. ${ }^{39}$

Second, it is also extremely unclear what Sartre's attitude to metaphysics amounts to. On the one hand, Sartre insists on the impropriety of extending categorial concepts that belong to the for-itself beyond its sphere. This seems to suggest that metaphysics is simply impossible, even if the question of the upsurge of the for-itself is cogent. ${ }^{40}$ On the other hand, Sartre asserts that 'metaphysics must nevertheless attempt to determine' (BN 621) the explanation for the upsurge of the for-itself, and since nothing in his philosophical apparatus allows for the intelligibility of unanswerable metaphysical questions (compare Kant, Schelling or Heidegger), ${ }^{41}$ it would seem that Sartre must be interpreted as affirming the possibility, in some fashion, of metaphysics' success.

${ }^{39}$ This is suggested by Sartre's talk of ontology as 'furnish[ing] information which serve as the basis for metaphysics'
(BN 620). Seel, Sartres Dialektik, p. 218, suggests that ontology is enquiry proceeding from the cogito, metaphysics, from being. As a further index of Sartre's unclarity, the description of metaphysics here at BN 619 may be contrasted with the quite different definition at BN 297, where Sartre says that 'metaphysics must conclude with a "that is" - i.e. in a direct intuition of [absolute] contingency'.

${ }^{40}$ Seel, Sartres Dialektik, p. 217, says that Sartre's ontology is grounded initially through a critique of metaphysics, to which its relation is negative, but that, because Sartre's own standpoint is metaphysical, Sartre is forced to recognise a positive relation to metaphysics in the Conclusion to Being and Nothingness.

${ }^{41}$ This claim is important for what I go on to argue and may be thought to require further defence. It is supported in the first place by the fact that Sartre nowhere affirms limitations on philosophical cognition: Sartre deploys the notion of 'factual' or 'contingent necessity' (discussed earlier) in contexts where philosophical explanation is seen to come to an end and where the option of allowing a metaphysical question to be intelligible but unanswerable can be supposed to present itself. In any case, in order for Sartre to be in a position to pursue this option without jeopardising his claim to philosophical success, the unanswerability of the relevant metaphysical questions would need to be explained from within his system: if it is not to indicate a failure of his system, then it must be shown to be a necessary consequence of our cognitive power. And for this to be done, his theory of philosophical cognition (which, as it stands, is not well developed) would need to be reconstructed in a way that (first) leaves a logical gap - of the sort created by Kant's distinction of schematised and unschematised categories, Schelling's distinction of negative and positive philosophy, and Heidegger's distinction of the ontic and the ontological - between that what can be thought as a metaphysical possibility 
The importance of these points for the earlier discussion of intersubjectivity is this. The Intersubjective Metaphysical Structure which, I suggested, lies just over the horizon of Sartre's treatment of other minds, counts in terms of the distinction drawn here as metaphysics rather than ontology: the move from my 'sort of cogito concerning' the other to Intersubjective Metaphysical Structure parallels the move from identification of the structure of being-for-itself to its explanation by metaphysics. Now, if Sartre's distinction of metaphysics from ontology were sound, and if Sartre had good reason for holding philosophical enquiry back from metaphysics, then there would be reason for rejecting the proposed Fichtean extension to his theory of intersubjectivity. If, however, as I have just argued, Sartre's distinction has no such force, then there is no basis for separating Sartre's cogito-like characterisation of intersubjectivity from Fichte's idea of metaphysical structure, and no obstacle to uniting them.

and what can be known as metaphysical truth, and (second) shows how the latter may fall short of the former. Even if this reconstruction could be provided without undermining directly any of Sartre's tenets, the deeper point is that the admission of unanswerable metaphysical questions would be strictly antithetical to Sartre's aim of making us philosophically transparent to ourselves in the way that, he believes, is required for our total responsibility. This view may be challenged, of course, since it is not a logical truth that total responsibility requires total philosophical selftransparency - Kant, for one, rejects it, arguing that philosophical limitation is a constitutive condition of the kind of autonomy that we are capable of - but Sartre's affirmation of it is prima facie well grounded. If our metaphysical insight is limited, then there are metaphysical possibilities which are incompatible with our possession of freedom (of the kind that Sartre considers it necessary to defend philosophically) which we cannot rule out, and our self-ascription of freedom would thus be uncertain, a merely probable, provisional or regulative assumption; Kant's own harmonisation of metaphysical ignorance with freedom, it should be noted, is based on a moral interpretation of freedom which is rejected by Sartre. In addition, the failure to achieve total explication would leave Sartre's claim for the reality of human freedom floating, in so far as, in the absence of any discursive proof of freedom, its philosophical deduction is intended to lie in the completeness of the phenomenological ontology supplied by Being and Nothingness as a whole. This all-or-nothing outlook, whereby the reality of freedom is tied to the achievement of philosophical systematicity, is once again explicit in Fichte. Iris Murdoch's designation of Sartre as a latter-day rationalist, in the sense of sharing the commitment to total explanation, is therefore apt. 
2. Having explored the idea of a project of founding stemming from the in-itself, Sartre turns to the question of the unity of being as a whole. The fact that the 'hiatus' (BN 621) between being-in-itself and being-foritself cannot be bridged by the metaphysical hypothesis that the in-itself gives birth to the for-itself in order to found itself, rules out one way of conceiving the totality jointly composed by being-in-itself and beingfor-itself. This does not, however, rule out some other conceptualisation of that totality. Sartre goes on to affirm that, since 'consciousness is bound to the in-itself by an internal relation', 'it is articulated with the initself so as to constitute a totality', one 'which would be given the name being or reality' (BN 621). Of what nature would this totality be? Sartre observes that if we are going to succeed in forming the required concept of total being, then 'it is necessary that the diversity of its structures [i.e. of in-itself and for-itself] be held within a unitary synthesis in such a way that each of them considered apart is only an abstraction' (BN 622), i.e. we must form a concept of an 'indissoluble totality of in-itself and for-itself' (BN 622). Now the only way in which we can do this, Sartre asserts, is by thinking of the in-itself as caused to exist by consciousness of it. (For, he reasons, while it is clear that the for-itself is indissolubly tied to the in-itself, the latter appears as independent of the former; so the only route to indissoluble totality - a totality in which neither term can exist without the other - lies through some sort of idealism regarding the in-itself.) And the concept of a being-for-itself that can create being-in-itself, Sartre asserts, is equivalent to the concept of a 'being which is its own "self-cause"', an 'ens causa sui' (BN 622), a concept of 'ideal being' (BN 623). This Spinozistic concept, according to Sartre, 'is impossible', for it 'includes a contradiction' (BN 622). Yet it is a concept which we legitimately and necessarily employ, since the for-itself is precisely 'a project of being its own self-cause' (BN 622): 'we define ourselves a priori by means of a pre-ontological comprehension of the ens causa sui' (BN 622).

On this new basis Sartre returns to his earlier conclusion that the unity of being as a whole consists in an incomplete teleological movement. From the point of view of the concept of ideal being,

'the real is an abortive effort to attain to the dignity of the self-cause. Everything happens as if the world, man, and man-in-the-world succeeded in realizing only a missing God. Everything happens therefore as if the in-itself and the for-itself were presented in a state of disintegration in relation to an ideal synthesis. Not that the integration has ever taken place, but on the contrary precisely 
because it is always indicated and always impossible. It is this perpetual failure which explains both the indissolubility of the in-itself and of the for-itself and at the same time their relative independence. Similarly when the unity of the cerebral functions is shattered, phenomena are produced which simultaneously present a relative autonomy and which can be manifested only on the ground of the disintegration of a totality. It is this failure which explains the hiatus which we encounter [... the totality is to be regarded as] a synthesis [which] is arrested before its completion, fixing the terms in a relative dependence and, at the same time, in a relative independence [...] it is in the form of a disintegrated ensemble that it presents itself to us in its ambiguity [... we find ourselves with the] notion of a detotalised totality'. (BN 623)

3. The foregoing has shown that Sartre regards metaphysics as bound to teleological notions and to conceptions of the absolute or unconditioned, just like the German idealists, and that he grants the legitimacy of metaphysical speculation. ${ }^{42}$ Given that, as I argued, there is no real distinction in Sartre between metaphysics and ontology, this indicates a deep convergence of Sartre's philosophy as a whole with German idealism.

It may be asked if Sartre can rightfully hold the view that metaphysics, conceived in German idealist terms, is legitimate. Are not teleological concepts restricted to the sphere of the for-itself, for Sartre? Does not consistency require Sartre to reject teleologically framed metaphysical hypotheses as mere mythology?

While it is true that the in-itself cannot exhibit a teleological character in the sense that it cannot present itself phenomenologically as a place in which the for-itself is 'at home', in e.g. the way that Kant thinks beautiful nature displays the empirical world to us, it does not follow that the general ontological fact of the existence of in-itself cannot, for Sartre, have a teleological explanation: he can consistently propose a teleological explanation for the existence of something that can only appear as alien, a teleological explanation for non-teleological appearance. It is true that two specific teleological possibilities are excluded for Sartre: first, that God is the bearer or source of the teleology in question, and second, that we as human beings, are the telos in question. The first is excluded because the concept of God, according to

\footnotetext{
${ }^{42}$ It is noteworthy, in support of my claim, that Merleau-Ponty's extended discussion of Sartre in ch. 2 of The Visible and the Invisible ('Interrogation and dialectic') treats him very much in these terms.
} 
Sartre, is contradictory, the second because in so far as we are human, i.e. divided between facticity and transcendence, we fail to realise the concept of 'ens causa sui'. But Sartre himself gives the justification for the for-itself's assigning teleological structure to the totality of being: however we consider the matter, the upsurge of the for-itself is an objective ontological event (Sartre is not an eliminativist materialist) - it is 'the absolute event which comes to being' (BN 619) - and since the form of being-for-itself is the form of a project, the category of teleology does allow itself to be employed with reference to being at large.$^{43}$ Sartre's reasoning here follows exactly the pattern of German idealism when it takes self-consciousness, regarded as radically unlike all other things, as the metaphysical clue to the understanding of being as a whole.

4. The fundamental methodological kinship of Sartre with German idealism just indicated is matched at the level of more specific metaphysical claims.

(1) The story that Sartre first tells of being as a whole, of the in-itself as attempting to found itself by engendering the for-itself, bears a striking similarity to Schelling's speculation in his treatise on human freedom:

'A consideration which proceeds from Things leads [... us to recognize] that the concept of becoming is the only one adequate to the nature of things. But the process of their becoming cannot be in God, viewed absolutely [...] But since there can be nothing outside God, this contradiction can only be solved by things having their basis in that within God which is not God himself, i.e. in that which is the basis of his existence [Grund von Existenz]. If we wish to bring this Being nearer to us from a human standpoint, we may say: It is the longing which the eternal One feels to give birth to itself. This is not the One itself, but is co-eternal with it. This longing seeks to give birth to God, i.e. the unfathomable unity [...] it is a will: but a will within which there is no understanding [...] not a conscious but a prescient will'. (Philosophical Enquiries into the Nature of Human Freedom, pp. 33$4 ; 358-9)$

\footnotetext{
${ }^{43}$ Sartre's reasoning is spelled out at BN 619-20. It is important to remember that Sartre's in-itself is not equivalent to matter, so the arguable impossibility of matter's exhibiting mentalistic properties presents no obstacle to the in-itself's being ascribed a teleological character.
} 
The echoes of Sartre are clear: Sartre's problem - of how there can be a transition from in-itself to for-itself, which is the condition of individuated determinate being - parallels Schelling's problem of the whence of Things; Schelling's problem of how to get the manifold of Things out of God, who is 'unfathomable unity', 'the absolute being of absolute identity' (ibid, p. 32; 358), parallels Sartre's problem of squeezing nothingness out of the pure being of the in-itself. Schelling's solution, of a 'longing to give birth to itself', parallels Sartre's idea of being's 'project of founding itself', just as Schelling's 'prescient' but non-conscious longing corresponds to the original 'presence to self' that Sartre says this project would require. Schelling and Sartre are both in the business of conceiving a teleology embedded in being, prior to human (and divine) subjectivity, a 'will within which there is no understanding'. Schelling's metaphysics is not Sartre's - Sartre rejects the story told by Schelling, because he denies the possibility of prescience without consciousness but their points of disagreement can be identified with precision only because the nature of their lines of speculations are so fundamentally similar.

(2) Sartre's relation to Spinoza follows a pattern that is familiar from and unique to German idealism: Spinoza stands just over the horizon from Sartre's dualism in exactly the way that he figures for the German idealists as the beckoning antidote to Kant's dualism, and in such a way that Sartre's final position corresponds closely to that of Schelling in his System of Transcendental Idealism.

This is shown in Sartre's solution to the idealism and realism opposition. Other solutions to this problem in existential phenomenology - those of Heidegger and Merleau-Ponty - try to overcome this opposition by dissolving the very notion of (in)dependence, showing it to be void of meaning at the crucial point where the idealist and realist each assert an arrow of dependence running one way or the other between subject and object. Heidegger and Merleau-Ponty's demonstrations in each case depend on the attribution of an error: for Heidegger, realism and idealism are theses which presuppose the subjection of Being to the mode of Zuhandensein; for Merleau-Ponty, they presuppose 'objective thought'. Sartre cannot do the same, however, because he is fully committed to the integrity of the notion of dependence in its application to the relation of subject and object, i.e. to the propriety of employing the concept of (in)dependence in an absolute sense. This commitment follows from his basic view of the nature of in-itself, consciousness and their relation, as he spells it out in, for example, his Ontological Proof. What Sartre does 
instead is assert that the totality of being 'presents itself to us in its ambiguity, that is, so that one can $a d$ libitum insist on the dependence of the beings under consideration or on their independence' (BN 623): the terms that compose the totality are fixed 'in a relative dependence and, at the same time, in a relative independence' (BN 623). The result is that being-for-itself can be regarded either as asymmetrically dependent on being-in-itself (realism) or as founding being-in-itself (idealism); where each alternative corresponds to one of the two conceptions of being-in-itself distinguished earlier - the first to the conception of being-in-itself as such, the second to the conception of being-in-itself as phenomenon. Realism and idealism thus come out as truths that coexist without contradiction: they are false positions only in so far as they understand themselves as negations of one another.

This strategy of overstepping the great opposition of realism and idealism, of Spinoza and Kant, by shaping their relation in such a way that they can be grasped as two sides of the same coin, is Schelling's. Heidegger or Merleau-Ponty are also, as said above, in the business of affirming a kind of monism, but their way of doing this contrasts with Schelling's: while it is essential for Schelling that the notions of ideality and reality should, in the form of what he calls 'potences', have unrestricted application - in order that their difference can then be the topic of an absolute identity - Heidegger and Merleau-Ponty deny that the relevant categories get a grip at the highest point of philosophical reflection; the non-application which they affirm of the theses of idealism and realism thus precludes the Schellingian concept of a point of indifference of realism and idealism. Heidegger and Merleau-Ponty deny the coherence of either monism or dualism. Sartre, like Schelling, affirms a monism which is identical with a dualism.

(3) What differentiates Sartre's version of 'Kantian Spinozism' from Schelling's is his account of what underlies the 'ambiguity' of total being, i.e. of what makes possible the standpoint from which realism and idealism can be grasped as relative truths. For Sartre, this is supplied by the conception of the totality of being as a synthesis which 'is arrested before its completion', consequently as something which exists 'in the form of a disintegrated ensemble'. For Schelling (after 1800), the relevant role is played by the notion of absolute identity (a version of causa sui, which Sartre rejects).

Now what may be noted is the manner in which Sartre here, while accepting Schelling's fundamental premise that it is the task of philosophy to think the unconditioned, the totality of being, engineers an outcome which is opposed to Schelling's conception of absolute identity, by deploying two 
ideas which are found in Schelling's predecessors. First, in holding that reality exists only 'in the form of a disintegrated ensemble', Sartre is, in effect, reemploying the form of solution that Kant offers to the mathematical antinomies: just as Kant holds that the empirical world does not exist as a determinate whole, so Sartre holds that total being does not exist as a determinate whole. This of course immediately creates a puzzle: how can reality as a whole be thought to not exist as a whole? While Kant's denial that the empirical world comprises a complete and determinate whole is explained by its status as subject-relative mere appearance, Sartre obviously cannot say the same, or anything analogous, about the totality of being. The solution to this difficulty is supplied by Sartre's second 'borrowing', which is from Fichte. In considering reality as a 'disintegrated ensemble' or 'arrested synthesis', we are measuring and viewing it through the lens of the concept of ideal being, causa sui, a concept which is implicated in our own being as for-itself. The totality of being exists, therefore, for Sartre as something 'disintegrated' because its fundamental character is that of a project - just as Fichte in the 1794 Wissenschaftslehre solves the problem of the incomplete syntheses of theoretical reason by subsuming them into the infinite task of practical reason. The absolute is thus attained for Sartre, as for (the earlier) Fichte, through practical concepts, and ultimately through the use of a regulative, unrealisable concept.

5. Sartre's convergence with German idealism can be indicated from many other angles, which space does not allow to be amplified but some of which may be mentioned very briefly. Several concern themes referred to earlier. Sartre's use of ontology to 'answer' epistemology, which can appear, as noted earlier, to reflect a rather contradictory relation to Heidegger, has a much closer model in Schelling's attempt to provide an ontological analysis of knowledge. ${ }^{44}$ Sartre's notion of 'contingent necessity' is employed explicitly by the later Schelling in the metaphysics and methodology of his anti-Hegelian 'higher empiricism'. The concept of a negative ontological relation which I suggested is crucial for Sartre's theory of intersubjectivity belongs to a tradition of conceptualising transcendental requirements as force-like, which goes back to Fichte's Wissenschaftslehre and Schelling's Naturphilosophie. Sartre's distinction of consciousness from the degraded 'psychic' has an exact parallel in, and may be elucidated by reference to, Fichte's distinction of activity from representation (Reinhold's 'Tatsachen' or 'facts of consciousness') and his

\footnotetext{
${ }^{44}$ For example in System of Philosophy in General, pp. 141-8.
} 
accompanying account of the mistaken substitution of repose or determinacy for activity. ${ }^{45}$ The general notion reflected in Sartre's doctrine of the degraded status of common sense conceptions of the mental - viz. that it is necessary, in order to salvage human freedom, to 'invert' the world of natural consciousness - is a constant theme in German idealism.

A further, obvious but important point may be added. Sartre's theses regarding the structure of the self - its identity and non-identity in reflection, and its temporal ekstases - remain merely paradoxical or metaphorical if not read as an instance of speculative logic's identity-in-difference. ${ }^{46}$ Sartre's claims regarding the subordinate status of logic - that the principle of identity is only a regional synthetic principle (BN xli-xlii), and that the original choice is prior to (and involves a choice of) logic (BN 570) - make possible, even if they do not require, his use of German idealism's speculative method. If this seems surprising, in view of Sartre's not seeming to share the aims of monism, systematicity and Vereinigung that motivate German idealism's conception of speculative thought, the answer is, I suggest, that although Sartre is indeed generally interested in oppositions rather than unities, the status of his oppositions - their internal and constitutive character - puts them on a metaphysical par with the unities of German idealism: Sartre's structures of (unsynthesisable, 'detotalised') opposition are thinkable only with the aid of the same conceptual machinery as German idealism employs in forming its conceptions of totality.

I hope to have shown in this section that Sartre's conception of philosophical explanation, and his commitment to its completeness, requires that his phenomenological ontology be supplemented with a metaphysics that bears the stamp of German idealism. This resituation of Sartre's metaphysics supports the Fichtean interpretation of his theory of intersubjectivity, and also returns us to an earlier point: in view of Sartre's preparedness to speculate teleologically on the totality of being, the thought that self and other similarly comprise a teleological unity becomes more compelling. ${ }^{47}$ If there is a teleological link between in-

\footnotetext{
${ }^{45}$ See in particular Attempt at a New Presentation, Chapter One, esp. p. 117.

${ }^{46}$ See Frank, Zeitbewußtsein, pp. 110-13.

${ }^{47}$ A faint trace of a teleological characterisation of intersubjectivity is in fact present in Being and Nothingness, in the description that Sartre gives there of the Other as 'reinforcing' my selfness (BN 283, 289). I have not put any weight on this point, however, because of the obscurity of the notion of 'reinforcement' used in this context (see note 16 above).
} 
itself and for-itself, then why may there not be, as Fichte, Schelling and Hegel suppose, a similar bond between for-itselves? This thought is, in fact, central to Sartre's ethics.

\section{Sartre's ethics}

Sartre's claim (BN 628) to be able to furnish an ethics presents well-known difficulties. To many commentators, Sartre has appeared to espouse an extreme subjectivism, barely distinguishable from emotivism and no more capable of being taken seriously as an ethical theory. In fact, Sartre's published statement of his ethical position, Existentialism and Humanism, contains an explicit affirmation of familiar Kantian principles: Sartre there rehearses one by one, in modified form, the universal-law, end-in-itself, and kingdom-of-ends formulas of the categorical imperative (pp. 31, 51-2), and he supposes that these may guide moral reasoning.

The puzzle, however, lies in their ground or derivation. Sartre appeals in Kantian fashion to the necessity of avoiding contradiction (p. 51), but he would appear to lack the apparatus - the distinctions of practical and theoretical reason, of duty from inclination, etc. - employed by Kant in his deductions of the moral law, while Sartre's outright identification of self-consciousness with autonomy appears to undermine Kant's attempt to argue for morality as a condition of achieving autonomy.

The suspicion thus forms, and it has been voiced by Sartre's critics, that in Sartre's hands the concepts of freedom and responsibility have come adrift from their Kantian moral moorings and become merely rhetorical devices for expressing the agonies of individual choice.

The route to discovering in Sartre a ground for morality lies in the Cahiers pour une morale, composed in 1948. The material in this unpublished and uncompleted work shows that Sartre envisages basing ethical requirements on a teleological ontology. ${ }^{48}$ Ethics is conceived by Sartre as originating in the stance taken up towards freedom by the subject who escapes from 'réflexion complice' and the project of becoming being-in-itself-for-itself, and who thereby achieves 'conversion'. Conversion is not simply a matter

\footnotetext{
${ }^{48}$ What follows draws substantially on Perna, 'Jean-Paul Sartre's Ethics of Authenticity', and refers to pp. 484-543 of the Cahiers. Perna defends in 'Bad faith and self-deception' a view of Sartre's theory of inauthenticity which parallels the view of Sartre's theory of intersubjectivity defended above.
} 
of altered subjective attitudes and intentions but is equivalent to the formation of a new order of being: 'elle réalise un type d'unité special à l'existant qui est l'unité morale' (p. 496), 'un type nouveau qui est l'accord avec soi' (p. 495). The ethical conduct that issues from conversion amounts to a new mode of "faire qu'il y ait de l'Etre" (p. 502). The false and impossible perfectionism of becoming causa sui gives way to a perfectionist ethic of freedom marked by the new self-relation and practical self-determination posited through conversion, which refers to and aims at being as a whole: 'But absolu: donner la liberté humaine comme fondement à l'être du monde' (p. 486; a highly Fichtean notion); 'Le dévoilement se fait selon le seul propos de dévoiler le maximum d'être en étant le plus soi-même' (p. 503). By this means, Sartre adds a new level to the description of intersubjectivity in Being and Nothingness, which is described in the Cahiers as concerning itself with merely 'l'Enfer des passions' and as restricting revelation of the Other to 'pur dépassement' (p. 515): the new, ethical mode of revelation of the Other, post-conversion, makes it possible that the Other 'me fait exister comme liberté existant aussi comme Etre-objet' (p. 515).

The indistinct argument of Existentialism and Humanism is here clarified, and the appearance which that text gives of Kantian deontology shown to be misleading: ${ }^{49}$ Sartre's adherence to Kantian ideas rests on a perfectionism which in turn proceeds from ontology; 'the plane of authenticity' (p. 52) which delivers the Kantian form of morality is grounded in teleological ontology. (This strategy was in fact hinted at, though not in a way that allowed it to be grasped, in the concluding 'Ethical implications' section of Being and Nothingness, where Sartre described the ideal of being-for-itself-in-itself as giving way to the ideal of freedom.)

Since the affirmation of freedom in conversion realises itself in ethical relations to others, the manifold of for-itselves is now conceived as forming a teleological unity. Ultimately, then, Sartre does make a correction to his theory of intersubjectivity that goes in the direction of German idealism - not for the

\footnotetext{
${ }^{49}$ More precisely, the Cahiers allows one to see that the deontological note struck loudly in Existentialism and Humanism - which no doubt owes something to its polemical intention, to deflect charges of anti-humanism, an aim well served by an alliance with Kant - does not correspond fully to the position that Sartre in fact adopts in this text: its argument unfolds to deliver the conclusion that freedom is an 'overruling aim' (p. 53), an object of 'quest' (p. 51), 'to be determined' (p. 55), furthermore, at a collective level, phrases that are suggestive of a perfectionist rather than a strictly deontological interpretation of freedom.
} 
reasons given above, and without ever going back to revise explicitly the argument of Being and Nothingness, but by way of reflection on what is required for ethical theory.

There are other writings after Being and Nothingness where Sartre makes essential use of teleological characterisations of the relation of the for-itself to the in-itself, and collapses the earlier distinction of metaphysics and phenomenological ontology. In the manuscript published as Truth and Existence - composed in 1948, the same year as the Cahiers - Sartre employs the notion that consciousness or being-for-itself exists in order that Being should be revealed. ${ }^{50}$ Sartre is concerned in this text with a cluster of questions which Being and Nothingness neglects or to which it gives only incomplete answers, questions of objectivity, intersubjective validity, the nature and criterion of truth, and so on. The notion that consciousness or the for-itself not only reveals being, but that its 'destiny' is to do so, provides the basis of Sartre's account of truth and objectivity, and gives him occasion to reemploy the strategy of extracting ethical conclusions from teleological ontology: ${ }^{51}$ the teleological-revelatory relation of the individual subject to being is extended by Sartre to the communication of truth between subjects, which thereby acquires the character of a virtue - giving truths to others is an instance of 'generosity', and an affirmation of the shared freedom which makes truth-giving necessary (truth 'is a demand of revealing freedom, which, as freedom, exists only in and through its effort to make the Other be free', p. 68).

\section{Existential phenomenology and German idealism}

Sartre sometimes pictures his philosophy as simply antithetical to Hegel's 'totalitarianism' in the manner of Kierkegaard: 'Here as everywhere we ought to oppose to Hegel Kierkegaard, who represents the claims of the individual as such' (BN 239). It is more accurate, I have suggested, to regard Sartre as developing a nonHegelian form of absolute idealism that coincides at important points with Fichte and Schelling. That Sartre should converge on their positions without, it seems, ever having engaged in close study of their works, is

\footnotetext{
${ }^{50}$ We find an echo of the idea earlier at for example BN xxxvii and BN 618: 'For consciousness there is no being except for this precise obligation to be a revealing intuition of something.' Here the talk of 'obligation' can perhaps be read as mere metaphor, but in Truth and Existence it cannot.

${ }^{51}$ See esp. pp. 4-6, 9, 13-20, 29-30, 66-7.
} 
explained, I suggest, by his simultaneous endorsement of the broad terms of reference of German idealism and rejection of Hegel's execution of the German idealist project: Sartre ends up in the space of nonHegelian German idealism through negative extrapolation from (as it were, 'undoing') Hegel.

Sartre's relation to non-Hegelian German idealist metaphysics is however, as has been seen, not free from ambiguity: there is a general tension within Sartre's philosophical project in Being and Nothingness, which comes to the fore in its account of intersubjectivity. Commentators who have noted this tension previously have attributed it to an unstable methodological mix in Sartre. ${ }^{52}$ Tentatively, I would suggest that it be interpreted as a general characteristic of existential phenomenology, in the following sense. Sartre, Heidegger and Merleau-Ponty seek to appropriate the strengths of German idealism - its robust antinaturalism, its axiological import, and its claims to 'absolute' conclusions, much stronger than those of Kant - while dispensing with its project of pushing transcendental metaphysics to the limit; they aim at overturning the empiricist-realist ways of thinking that contaminate the commonsensical natural attitude without accepting the need for further speculative grounding of their conclusions. In so far as German idealism has, of course, its own share of problems, this is an entirely coherent and well-motivated undertaking. The interesting question, however, is whether the distance that existential phenomenology thinks it has from German idealism can really be maintained. Critical discussion of this broader question might well lead us to conclude, I think, not of course that existential phenomenology merely repeats German idealism, but that the new territory it uncovers is better regarded as a series of supplements to, continuations, and extensions of German idealism, than as a fundamentally distinct philosophical programme ${ }^{53}$ What I have said here about Sartre does not of course bear out this generalisation, but I hope to have made it seem at least a line of thought worth investigation. ${ }^{54}$

\footnotetext{
${ }^{52}$ See the references in notes 23 and 40, and Natanson, 'The problem of others in Being and Nothingness'.

${ }^{53}$ I argue for this conclusion with respect to Merleau-Ponty in 'Merleau-Ponty's transcendental theory of perception'.

${ }^{54}$ This paper was stimulated, and is informed by discussions of Sartre organised by the European Journal of Philosophy in London and Berlin, with the participation of David Bell, Peter Bieri, Elizabetta Galeotti, Stefanie Grünberg, Axel Honneth, Rolf-Peter Horstmann, Robert Pippin, Mark Sacks and Bob Stern. I am also grateful to those who provided me with comments on an earlier draft of this paper presented at the University of Southampton, to two anonymous readers
} 


\section{References}

Aquila, Richard E., 'Sartre's other and the field of consciousness: a Husserlian reading', European Journal of Philosophy 6, 1998, 253-76.

Catalano, Joseph S., A Commentary on Jean-Paul Sartre's 'Being and Nothingness' (Chicago: University of Chicago Press, 1974).

Fichte, J. G., Foundations of the Entire Wissenschaftslehre (1794), in The Science of Knowledge, ed. and trans. Peter Heath and John Lachs (Cambridge: Cambridge University Press, 1970).

Fichte, J. G., Foundations of Natural Right, trans. Michael Baur, ed. Frederick Neuhouser (Cambridge: Cambridge University Press, 2000).

Fichte, J. G., Attempt at a New Presentation of the Wissenschaftslehre (1797/98), in Introductions to the Wissenschaftslehre and Other Writings (1797-1800), trans. and ed. Daniel Brezeale (Indianapolis: Hackett, 1994).

Fichte, J. G., The Vocation of Man (1800), trans. Peter Preuss (Indianapolis: Hackett, 1987).

Frank, Manfred, Zeitbewußtsein (Pfullingen: Neske, 1990).

Gardner, Sebastian, 'Value and idealism', in Philosophy, the Good, the True and the Beautiful, ed. Anthony O'Hear (Cambridge: Cambridge University Press, 2000).

Gardner, Sebastian, 'German idealism I', Aristotelian Society Supplementary Volume 76, 2002, 211-28.

Gardner, Sebastian, 'Merleau-Ponty's transcendental theory of perception', in Perception, ed. Michael Martin and Martin Stone (London: Routledge, 2004).

Hartmann, Klaus, Sartre's Ontology (Evanston: Northwestern University Press, 1966).

Honneth, Axel, 'Erkennen und Anerkennen: zu Sartres Theorie der Intersubjectivität', in Unsichtbarkeit: Stationen einer Theorie der Intersubjektivität (Frankfurt am Main: Suhrkamp, 2003).

Jacobi, F. H., Main Philosophical Writings and the Novel Allwill, trans. and ed. George di Giovanni (Montreal: McGill-Queen's University Press).

for the Journal of the History of Philosophy for helpful suggestions, and to the Arts and Humanities Research Board and the Philosophy Department of University College London for research leave that enabled its completion. 
Merleau-Ponty, Maurice, Phenomenology of Perception (1945), trans. Colin Smith (Routledge, 1962).

Merleau-Ponty, Maurice, The Visible and the Invisible. Followed by Working Notes (c. 1959-61), trans. Alphonso Lingus (Evanston, Ill.: Northwestern University Press, 1968).

Natanson, Maurice, 'The problem of others in Being and Nothingness', in Paul Arthur Schilpp ed., The Philosophy of Jean-Paul Sartre (LaSalle, Illinois: Open Court, 1981).

Perna, Maria Antonetta, 'Jean-Paul Sartre's Ethics of Authenticity. An Analysis and Defence' (PhD, University of London, 1999).

Perna, Maria Antonetta, 'Bad faith and self-deception: reconstructing the Sartrean perspective', Journal of the British Society for Phenomenology 34, 2003, 22-44.

Sartre, Jean-Paul, The Transcendence of the Ego: An Existentialist Theory of Consciousness (1936-37), trans. and ed. F. Williams and R. Kirkpatrick (London: Methuen, 1972).

Sartre, Jean-Paul, War Diaries: Notebooks from a Phoney War November 1939-March 1940, trans. Quentin Hoare (London: Verso, 1984).

Sartre, Jean-Paul, The Psychology of Imagination (1940), trans. Bernard Frechtman (London: Methuen, 1972).

Sartre, Jean-Paul, Being and Nothingness: An Essay in Phenomenological Ontology, trans. Hazel E. Barnes (London: Methuen, 1958) [L'être et le néant: essai d' ontologie phénoménologique (Paris: Gallimard, 1943)].

Sartre, Jean-Paul, Existentialism and Humanism (1946), trans. Philip Mairet (London: Methuen, 1973).

Sartre, Jean-Paul, Cahiers pour une morale (1947-48) (Paris: Gallimard, 1983).

Sartre, Jean-Paul, Truth and Existence (1948), trans. Adrian van den Hoven (Chicago: University of Chicago Press, 1992).

Schelling, F. W. J., System of Transcendental Idealism (1800), trans. Michael Vater (Charlottesville: University of Virginia Press, 1978).

Schelling, F. W. J., System of Philosophy in General and of the Philosophy of Nature in Particular (1804), in Idealism and the Endgame of Theory: Three Essays, trans. and ed. Thomas Pfau (Albany: State University of New York Press, 1994). 
Schelling, F. W. J., Philosophical Enquiries into the Nature of Human Freedom (1809), trans. James

Gutman (LaSalle, Illinois: Open Court, 1989).

Schroeder, William R., Sartre and his Predecessors: the Self and the Other (London: Routledge \& Kegan Paul, 1984).

Seel, Gerhard, Sartres Dialektik. Zur Methode und Begründung seiner Philosophie unter Besonderer Berücksichtigung der Subjekts-, Zeit und Werttheorie (Bonn: Bouvier, 1971).

Theunissen, Michael, The Other: Studies in the Social Ontology of Husserl, Heidegger, Sartre, and Buber, trans. Christopher Macann (Cambridge, Mass.: MIT Press, 1986).

Theunissen, Michael, 'Sartres negationstheoretische Ontologie der Zeit und Phänomenologie der Zeitdimensionen', in Negative Theologie der Zeit (Frankfurt am Main: Suhrkamp, 1997).

Williams, Robert R., Hegel's Ethics of Recognition (Berkeley: University of California, 1997).

Zahavi, Dan, Husserl and Transcendental Intersubjectivity: A Response to the Linguistic-Pragmatic

Critique, trans. Elizabeth A. Behnke (Athens: Ohio University Press, 2001). 